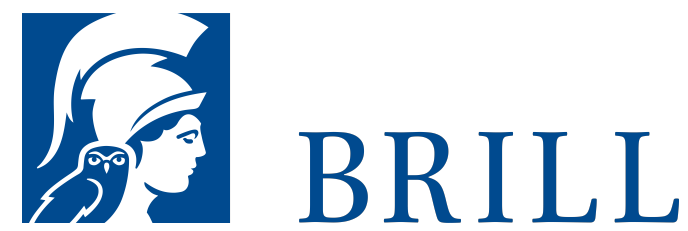

\title{
Varieties of Social Understanding
}

\section{Author: Anika Fiebich}

How do we understand other people's minds? This question has been discussed intensively in the theory of mind debate. 'Theory of mind' is defined as the capacity to attribute mental states to oneself and to others and to make use of that capacity in behavior understanding. This book offers a critical analysis of a variety of tasks that have been conducted to investigate the development of a theory of mind in children. The heart of the book is a pluralistic account of social understanding. Rather than relying on a default procedure of social understanding (e.g., theory or simulation), individuals understand the behavior of another person in various ways dependent on their cognitive competencies and the socio-situational context. As a rule of thumb, individuals are prone to make use of that procedure that is cognitively least effortful to them in a given context. Covering a wide range of studies, the implications of the pluralistic account are discussed with respect to culture and psychopathology. Finally, the book points to the role that social interaction may play in social understanding.

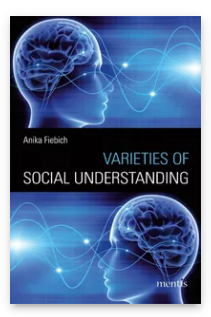

Pages: 215

Seiten

Language:

English

Subjects:

General,

Philosophy

Publisher: Brill | mentis

E-Book (PDF)

Released online:

27 Feb 2015

ISBN: $978-3-$

95743-920-8

List price

Paperback

Publication date:

27 Feb 2015

ISBN: 978-3-

95743-003-8

List price 
For more information see brill.com

Order information: Order online at brill.com +44330 333 0049 | customerservices@brill.com Submission information: brill.com/authors

Titles published by Brill | Fink, Brill | mentis or Brill | Schöningh: +49(o)715413279216| brill@brocom.de 